\title{
Practitioners' Evaluation On The Procedural Aspects Of An English Language Portfolio
}

Canan Karababa, Ankara University, Turkey

Sezgi Saraç Süzer, Başkent University, Turkey

\begin{abstract}
This study aims to share English language practitioners' reflections on the adaptation of teaching methods and materials during the pre-validation period of the European Language Portfolio $(E L P)$. In order to achieve this aim, a high school was selected as the scope of research, since it has started to adapt the English language teaching curriculum, syllabuses, instruction methods and assessment in line with the Common European Framework for the teaching of English as a foreign language for the last 4 years. A focus group of eight teachers was selected to collect data via semi-structured interviews. During the data collection procedure, the participants evaluated the process and procedures in terms of the related themes of SWOT analysis. The collected data was analyzed through coding and theme identification.
\end{abstract}

Keywords: European Language Portfolio, Common European Framework, Case Study, SWOT Analysis

\section{INTRODUCTION}

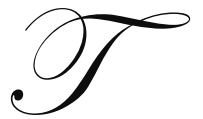

he European Union with 'no borders' gave the Council of Europe (CoE) the idea of overcoming 'communication borders' within Europe as well. Owing to Modern Languages Projects by the Council, the Common European Framework of Reference (CEFR), as an end-product, redefines the teaching of languages from various aspects; namely, language use, language learner, assessment and methodology. The CEFR provides "a common basis for the elaboration of language syllabuses, curriculum guidelines, examinations, textbooks, etc. across Europe" (CoE, 2001: I). Therefore, this guideline achieves standardization in language teaching, learning and assessment by targeting the improvement of communicative and intercultural competencies, and that of learners' autonomy.

As the most distinctive feature of CEFR, The Common Reference Levels provide a global scale of six levels, which are A1, A2, B1, B2, C1, and C2. All these levels with general descriptions of 'can-do' statements are offered in different taxonomies of 'understanding', 'speaking' and 'writing'. Within the framework, criteria of assessment for range, accuracy, fluency, interaction, coherence are accompanied by other scales on the areas of linguistic, socio-linguistic, strategic and pragmatic competences. While proposing the general framework of reference, the CoE does not impose "one single uniform system" of language learning and teaching. Instead, it offers flexibility and adaptation for different settings. Hence, the CEFR is defined as follows:

- $\quad$ Multi-purpose: usable for the full variety of purposes involved in the planning and provision of facilities for language learning

- $\quad$ Flexible: adaptable for use in different circumstances

- $\quad$ Open: capable of further extension and refinement

- $\quad$ Dynamic: in continuous evolution in response to experience in its use

- User-friendly: presented in a form readily understandable and usable by those to whom it is addressed

- Non-dogmatic: not irrevocably and exclusively attached to any one of a number of competing linguistic or educational theories or practices (CEF, 2001: 7-8).

CEFR functions as a theoretical guide to design language teaching programmes. On the other hand, in practice, the European Language Portfolio (ELP) is the means to achieve the Council of Europe's principle that 
language learners should be in the process of "social moderation" (Little, 2005: 325). With this end in view, ELP is designed in three main parts which are the Language Passport, Language Biography and Dossier.

According to the Principles and Guidelines approved by the Council of Europe (DGIV / EDU / (2003) 3), The Language Passport is to display the language learner's level of proficiency in languages at a definite period of time. The language level identifications included in this section are designed in line with the common reference levels in CEFR. This component allows for self-assessment, teacher assessment and assessment by educational institutions and examination boards. In the second section; namely, the Language Biography, the language learner plans, reflects on and assess both the learning process and progress. It also includes outclass experiences in terms of linguistic and cultural aspects. In the last section, the Dossier, the language learner keeps the archive of his or her achievements or experiences in the language.

\subsection{Aim}

This study aims to share English language practitioners' reflections on the adaptation of teaching methods and materials during the pre-validation period of the European Language Portfolio. To this end, the selected scope was a high school in which the English language teaching curriculum, syllabuses, instruction methods and assessment have been adapted in line with the CEFR for the teaching of English as a foreign language. The research questions targeted to be investigated during the data collection and analysis procedure are as follows:

According to the practitioners teaching English as a foreign language in Turkey,

1. what are the strengths of ELP?

2. what are the weaknesses of ELP?

3. what are the opportunities of ELP?

4. what are the threads of ELP?

\section{METHOD}

The selected method of inquiry for the research is case study. As has been put forward by Yin (1994), case study, as an empirical inquiry, "investigates a contemporary phenomenon within its real-life context..." (p. 13). Therefore, the context of research is limited to a high school in Turkey. The school has been selected as the setting and scope since the practitioners at the ELT department have been adapting the English language teaching curriculum, syllabuses, instruction methods and assessment according to the Common European Framework for the teaching of English as a foreign language for the last 4 years.

In order to collect qualitative data from participants, the researchers interviewed with the practitioners for two sessions, each of which lasted for nearly 80 minutes. The data was recorded to be transcribed and analyzed later on. While preparing the questions for interviewees, it is given utmost importance to the notion that the language and word choice improves the quality of data collected (Patton, 1990). Hence, the questions were designed in line with SWOT (strenghts, weaknesses, opportunities, threats) analysis technique. SWOT analysis provides the researchers to analyze a situation during a strategic planning process or in order to evaluate the capabilities of a situation (Foong, 2007). Besides, SWOT analysis is defined as a social activity of a group of people gathering together to share information in a systematic way (Stacey, 1993). Therefore, in this study, the participants, who are eight practitioners working at the ELT department of the same institution, came together to share their reflections on the procedural aspects of teaching through English language portfolio.

\section{FINDINGS}

\subsection{Strengths}

\subsubsection{Provides Standardization in Teaching and Learning}

One of the strengths identified by the participants is that the ELP provides standardization in teaching and 
learning. As stated, even if the class teacher changes, the learning progress is not ceased or interrupted and the students' language improvement is ensured. Besides, the ELP facilitates student mobility since it also functions as the record of students' language productions and language improvement.

\subsubsection{Improves Teacher and Student Autonomy}

Another strength of the ELP is the improvement of both teacher and student autonomy. The ELP related applications are stated to enable the students to set targets for individual improvement. Moreover, the students find the opportunity to improve self-esteem as well as to develop responsibility and self-discipline while learning the foreign language. The teachers also improve autonomy in teaching. As indicated, teachers try out new teaching materials and activities to be applied in classes. They organize the content of teaching depending on what their students need and are interested in.

\subsubsection{A Tool for Language Teaching and Assessment}

As another strength, the portfolio provides criteria for the identification of students' language level, which facilitates the teaching and assessment process for the practitioners. As for the students, the portfolio is stated to illustrate and report their personal language learning strategies, which enables the development of self-control and self-actualization to evaluate the whole learning process. What is more, the students are stated to find the opportunity to evaluate their own language productions, since the portfolio functions as a self-assessment tool, as well.

\subsubsection{Motivates Teachers and Students}

As the last and the most important strength, ELP development is claimed to increase both the students' and teachers' motivation. The ELP related applications are found to be motivating for students to learn the foreign language, and for teachers to teach English since the practitioners are challenged to develop new teaching materials and experience new instruction techniques. About motivation and ELP relation, the participants emphasized that ELP related applications are effective especially for the $9^{\text {th }}$ and $10^{\text {th }}$ grade students.

\subsection{Weaknesses}

\subsubsection{Procedure}

Among the data collected, one of the most repeated comments from the participants was that the procedure was not clear at all. With the term 'procedure' the participants defined the period which started on the date their school was nominated as the pilot school by the Ministry of Education in Turkey. Therefore, the term 'procedure' embraces both the period of getting prepared, and then teaching via the ELP. As the school was selected to develop an English language teaching curriculum in line with Common European Framework, the head of the English language teaching unit started to carry out inquiries on the ELP with the help of other teachers working for the same department. The participants stated that a specialist or counselor was not in charge to guide them, which caused waste of time on doing much research to understand what the ELP is. They indicated that since they were not guided by anyone knowledgeable on the ELP, they carried out some irrelevant work, such as focusing on making the learners collect their productions in personal files only.

In addition, the period of adapting the curriculum and instruction in accordance with ELP and the application process of teaching was found to be very demanding for the teachers. The participants claimed that the coursebooks for the teaching of English were not appropriate or sufficient for the ELP applications. Therefore, the teachers were required to develop materials and carry out activities different from the ones offered in coursebooks. Besides, the procedure was hard for the students in terms of grasping the purpose of ELP related applications, as they were used to traditional language learning techniques. The procedure was reported to be very demanding and ineffective especially for the $11^{\text {th }}$ graders. Since the students in the $11^{\text {th }}$ grade, last year of secondary education, focus on the university entrance exam only, the ELP related activities turn out to be too demanding for them. 


\subsubsection{Descriptors}

The other major theme indicates that the suggested descriptors are not efficient enough. The participants emphasized that the descriptors were not appropriate for the target group of students. They added that the descriptors did not match with the tasks they already used in classes. To the teachers, each student's quality of performance cannot be the same as stated in descriptors. Besides, each teacher's perceptions on descriptors vary and it is not always possible to negotiate on the content of descriptions to achieve standardization in teaching.

\subsection{Opportunities}

Two main groups of themes related with opportunities were identified within the data: One of these groups is student-related and the other is teacher-related opportunities. These groups of opportunities are as follows:

\subsubsection{For Students}

It was indicated by the participants that the ELP informs both students and parents about learner performance and development in the target language. Besides, the related applications prepare the students for university education in terms of autonomy and self-esteem. Lastly, the teaching and assessment methods preferred lower the students' fear of failure and exam anxiety.

\subsubsection{For teachers}

It is stated that the ELP enables objectivity in the assessment of students' performance. As the teachers negotiate on the assessment tools beforehand, they achieve both objectivity and standardization while evaluating students' work. Besides, even though the teachers think that it is a demanding process to develop checklist descriptors, self-assessment grids and to adapt teaching methods according to CEF, this period of adaptation is believed to have alleviated teachers' work load in the following academic years. As another opportunity, the participants put forward that teachers who are involved in the process of ELP adaptation during the pre-validation period started to give more importance to their own professional development, since they read more on the literature and produce more on teaching. Therefore, the participants claimed that the number of teachers with $\mathrm{MA}$ and $\mathrm{PhD}$ degrees will increase in the following years.

\subsection{Threats}

'Non-democratic' and 'non-cooperative' teachers were highlighted as the first two themes on possible threads of adaptation process. The participants emphasize that the whole process requires collaborative group work of colleagues at the ELT department. As stated, the teachers are supposed to discuss the content of all applications and negotiate on them. If there exist teachers who cannot handle respecting others' views in a democratic manner, or cannot contribute to progress cooperatively, the process is thought to be in danger and under threat. Moreover, the participants indicate that administrators who want to control in-class applications can also be threatening the process.

\section{CONCLUSION}

The results of this case study on the practitioners' evaluations indicate that the procedural aspects of application are not clear, and the practitioners are in the need of an advisor to consult on various issues such as coursebook selection, material development and adaptation of descriptors. So, either the Ministry of Education or the $\mathrm{CoE}$ is expected to assign an expert or a specialist to both guide and train the practitioners working for the pilot schools selected for ELP applications. As also stated by Glover et. al. (2005), in a pilot project done to check the efficiency of ELP at a university in Turkey, insufficient teacher training on the issue was one of the reasons why ELP was not successful in that context. Besides, as indicated by Scharer (2000) the theoretical basis previous to applications is indispensable for teachers to achieve efficiency in using the ELP while teaching. Therefore, it can be stated that continuous cooperative work with an advisor or trainer will probably enable the teachers to cope better with the aspects found to be demanding during the procedure. 
Via the ELP, it is aimed to make learners to think about their own learning which leads to fostering 'learner autonomy' at the end (Little \& Perclova, 2001). In addition to 'learner autonomy', the participants in this study also emphasized that the 'teachers' as well developed 'autonomy' in their professional life and career. Collaborative work and taking the initiative to design teaching in class encourage practitioners to explore their potentials in teaching. As it is also indicated by Arıkan (2004), English language teachers working in Turkey demand to be 'autonomous' in more individualized terms by spotting their own strong and weak points and then developing accordingly. Hence, it is seen that the ELP-related applications offer life-long learning opportunities not only for learners but also for practitioners.

Within the framework of curriculum design and revision for the school sector, the interference of government in education has been regarded as a threat for ELP applications (Bailly, et. al., 2002). The centralized system of education in Turkey might be a disadvantage; nevertheless, the practitioners indicate that 'nondemocratic' teachers and administrators are the major threat for the process. So, the practitioners' view enables us to approach the issue from a different perspective which is more basic, and it emphasizes the need for a revision from a 'bottom-up' direction to the democratization of education.

\section{AUTHOR INFORMATION}

Assist Prof. Dr .Z. Canan Karababa holds a PhD from Ankara University; specializing in Teaching Turkish as a foreign and native language. She currently works as a head of Foreign Languages Education Department at Faculty of Educational Sciences in Ankara University. She also lectures on Turkish Language and Culture in various universities abroad; in Trinity College, Bemidji State University. She enrolled in projects (EU (Grundvic and Commenious) and National projects with Ministry of Education) about Teacher Education. Her research areas are text books, teacher education, teaching and learning strategies, new methods in language teaching, material development, learner autonomy.

Dr. Sezgi Sarac Suzer holds a PhD from Hacettepe University, specializing in Teaching English as a Foreign Language. She currently works as an Assistant Professor at Baskent University in Turkey and is also the associate editor of the journal Novitas: ROYAL (Research on Youth and Language). Her research areas are curriculum development, pedagogical knowledge, material development and syllabus design.

\section{REFERENCES}

1. Arıkan, A. (2004). Professional development programs and English language instructors: A criticalpostmodern study. Hacettepe University Journal of Education, 27, 40-49.

2. Bailly, S., Devitt, S., Gremmo, M-J., Heyworth, F., Hopkins, A., Jones, B., Makosch, M., Riley, P., Stoks, G. and Trim, J. (eds.), (2002). Common European Framework of Reference for Languages: Learning, teaching, Assessment: A guide for users. Strasbourg: Council of Europe, Language Policy Division.

3. Council of Europe. 2001. the Common European Framework of Reference for Languages: Learning, Teaching, Assessment. Cambridge: Cambridge University Press. (also available at http://www.culture2.coe.int/portfolio/documents into/common framework.html.)

4. Council of Europe. (2000). European Language Portfolio (ELP): Principles and Guidelines. Strasbourg: Council of Europe. (Document DGIV/EDU/LANG (2000) 33).

5. Foong, L.M. (2007). Understanding of SWOT Analysis. http://article.tqmcasestudies.com/free-tqmebook/swot-analysis.pdf

6. Glover, P., et.al. (2005). Preparing for the European Language Portfolio: Internet connections. Turkish Online Journal of Distance Education-TOJDE, 6 (1), Available at: http://tojde.anadolu.edu.tr/tojde17/articles/mirici.htm [May 12, 2008].

7. Little, D. (2005). The Common European Framework and the European Language Portfolio: Involving learners and their judgements in the assessment process. Language Testing, 22, 321-336.

8. Little, D. \& Perclova, R (2001). European Language Portfolio: Guide for teachers and teacher trainers. Strasbourg, Council of Europe.

9. Patton, M. Q. (1990). Qualitative Evaluation and Research Methods. Newbury Park, CA: Sage. 
10. Scharer, R. (2000). Final Report A European Language Portfolio Pilot Projet Phase 1998-2000, DGIV/EDU/LANG (2000) 31rev, Strasbourg, Council of Europe.

11. Stacey, R. (1993). Strategic Management and Organisational Dynamics. London: Pitman.

12. Yin, R. K. (1994). Case Study Research: Design and Methods. $\left(2^{\text {nd }}\right.$ ed.) Thousand Oak, CA: Sage.

\section{NOTES}

